\begin{tabular}{|lll|}
\hline Diterima & $:$ & 22 Agustus 2019 \\
Direvisi & $:$ & 31 Oktober 2019 \\
Disetujui & $:$ & 16 Desember 2019 \\
Diterbitkan & $:$ & 27 Desember 2019 \\
\hline
\end{tabular}

\title{
EFEKTIVITAS PEMBELAJARAN KOMPUTER BERSERTIFIKAT LEMBAGA KURSUS DAN PELATIHAN PADA MATA PELAJARAN MUATAN LOKAL PAKET C
}

\author{
Ivo Yani \\ email: ivo.yani@kemdikbud.go.id \\ Pamong Belajar Balai Pengembangan Anak Usia Dini dan Pendidikan \\ Masyarakat Sumatera Utara
}

Jalan Kenanga Raya No. 64 Tanjungsari Medan

\begin{abstract}
Abstrak: Muatan lokal pada program Paket $C$ merupakan kajian yang diberikan secara terintegrasi dalam mata pelajaran atau secara tersendiri sebagai mata pelajaran pilihan. Struktur kurikulum mata pelajaran muatan lokal rumpun komputer merujuk pada Kurikulum Berbasis Kompetensi Direktorat Pembinaan Kursus dan Pelatihan Tahun 2009 dan disesuaikan dengan jumlah satuan kredit kompetensi (SKK) mata pelajaran muatan lokal Paket C. Pembelajaran komputer dilakukan di Lembaga Kursus dan Pelatihan (LKP) dan bagi peserta didik yang telah mencapai kompetensinya diberikan sertifikat. Penelitian ini bertujuan untuk menemukan (1) hasil belajar komputer pada mata pelajaran muatan lokal Paket $C$, dan (2) efektivitas pembelajaran komputer pada mata pelajaran muatan lokal Paket C. Penelitian ini adalah penelitian eksperimen yang dilaksanakan di empat PKBM Provinsi Sumatera Utara pada tahun pelajaran 2017/2018. Subjek penelitian adalah peserta didik tingkatan VI Derajat Kompetensi Mahir 2 yang berjumlah 33 orang. Desain eksperimen yang digunakan adalah eksperimen semu (quasi experiment design) dengan tes awal dan tes akhir. Instrumen pengumpulan data berupa tes sebanyak 20 butir soal pilihan ganda. Signifikansi program diuji dengan $t$-test berkorelasi. Hasil penelitian menunjukkan bahwa nilai $t$ hitung $>t$ tabel $(7,14>2,04)$, artinya terdapat perbedaan yang signifikan nilai yang diperoleh peserta didik sebelum dengan sesudah mengikuti pembelajaran komputer pada taraf signifikansi $5 \%$.
\end{abstract}

Kata-kata kunci: bersertifikat, muatan lokal, pembelajaran komputer

\section{EFFECTIVENESS OF CERTIFIED COMPUTER LEARNING LKP IN THE LOCAL LOAD STUDY PACKAGE C}

\begin{abstract}
Local content in the Package C Program is a study that is given in an integrated subjects or individually as elective subjects. The curriculum structure of the local content of computer subject cluster refer to the Competency-Based Curriculum of the Directorate of Course and Training in 2009 and adapted to the number of SKK in local content Package $C$. The computer learning is conducted by Institute of Training and Course (LKP) in which student participants who achieved certain competence would be given certificates. This study aims to find out (1) computer learning outcomes on Package $C$ local content subjects, and (2) computer learning effectiveness on Package $C$ local content subjects. This research is an experimental research at four PKBM North Sumatra Province PKBM 2017/2018 school years. This study involved 33 student participants of Level VI Degrees Advanced Competency 2. The experiment design used in this research is a quasi experiment design with initial tests and final tests. The instrument for data collection used is a test which consists of 20 multipe choice questions. The significance of the program was tested by a correlated $t$-test. The results showed that tcount $>$ ttabel $(7,14>2,04)$, which means that there is a significant value (level 5\%) obtained by students, before and after following computer learning.
\end{abstract}

Keywords: certified, computer learning, local content 


\section{PENDAHULUAN}

Pendidikan kesetaraan merupakan suatu bentuk realisasi dari Undang-undang Republik Indonesia Nomor 20 Tahun 2003 tentang Sistem Pendidikan Nasional (UUSPN) pasal 26 ayat (3) yang menyatakan bahwa "pendidikan nonformal meliputi salah satunya adalah pendidikan kesetaraan yang terdiri dari Paket A, Paket B, dan Paket C". Pendidikan Kesetaraan Paket $C$ adalah pendidikan umum pada jalur pendidikan nonformal yang berlangsung di luar sistem persekolahan dan dilaksanakan secara terstruktur dan berjenjang, setara dengan SMA/MA. Program ini ditujukan bagi peserta didik yang karena berbagai faktor tidak dapat mengikuti pendidikan di sekolah, putus sekolah, putus lanjut, usia produktif yang ingin meningkatkan pengetahuan dan kecakapan hidupnya. Juga bagi masyarakat yang memerlukan layanan khusus dalam memenuhi kebutuhan hidupnya sebagai dampak dari peningkatan taraf hidup, perkembangan ilmu pengetahuan dan teknologi. Program Paket C berfungsi untuk mengembangkan potensi peserta didik dengan penekanan pada penguasaan pengetahuan, keterampilan fungsional, dan pengembangan sikap, serta kepribadian profesional.

Pusat Data Statistik Pendidikan (PDSP) Kementerian Pendidikan dan Kebudayaan Tahun Ajaran 2017/2018 menyebutkan bahwa jumlah penduduk Indonesia yang putus sekolah tingkat SMA sebanyak 31,123 orang $(0,67 \%)$ sedangkan tingkat SMK sebanyak 73,384 orang (1,57\%). Di sisi lain, data dari Setjen Kemdikbud pada tahun 2016, masyarakat yang sudah terlayani pada pendidikan nonformal melalui pendidikan kesetaraan Paket $\mathrm{C}$ sebanyak 2459.717 orang dengan jumlah kelompok belajar sebanyak 6.897 buah. Dari jumlah tersebut, yang mengikuti ujian nasional sebanyak 101.002 dan yang lulus berjumlah 85.172 orang atau $83.33 \%$. Sedangkan ketersediaan pendidik 32.667 orang dan pengelola 11.646 orang. Dari data tersebut dapat kita maknai bahwa Pendidikan Kesetaraan Paket $\mathrm{C}$ sangat dibutuhkan masyarakat dan menjadi jawaban atas permasalahan putus sekolah.

Permendiknas RI No. 14 tahun 2007 Tentang Standar Isi Untuk Program Paket A, Program Paket B, dan Program Paket C mengamanatkan bahwa kekhasan Iulusan Paket $C$ adalah memiliki keterampilan berwirausaha. Dengan demikian peserta didik Pendidikan Kesetaraan Paket $\mathrm{C}$ tidak hanya membutuhkan muatan akademik saja melainkan juga membutuhkan muatan keterampilan. Muatan lokal (Muatan lokal) merupakan mata pelajaran wajib yang tercantum dalam struktur kurikulum Paket $\mathrm{C}$. Muatan lokal merupakan kegiatan kurikuler yang bertujuan mengembangkan kompetensi peserta didik sesuai dengan ciri khas dan potensi daerah, termasuk keunggulan daerah. Substansi muatan lokal ditentukan oleh satuan pendidikan; dapat berupa program keterampilan produk dan jasa. Jika substansi yang akan dikembangkan berisi materi yang tidak spesifik, dapat menjadi bagian dari mata pelajaran lain. Namun jika substansinya terlalu luas maka harus dikembangkan menjadi mata pelajaran tersendiri.

Setiap satuan pendidikan dapat melaksanakan muatan lokal lebih dari satu jenis dalam setiap semester, mengacu pada: minat dan atau karakteristik program studi yang diselenggarakan satuan pendidikan. Setiap peserta didik boleh mengikuti lebih dari satu jenis muatan lokal pada setiap tahun pelajaran. Selama ini pembelajaran muatan lokal yang diberikan kepada peserta didik Paket $\mathrm{C}$ belum menjadi penguatan, sehingga terkesan hanya sebagai pelengkap saja. Jenis keterampilan pada mata pelajaran muatan lokal Paket $\mathrm{C}$ ditentukan oleh pengelola dengan memberdayakan sumber-sumber yang ada di satuan pendidikan saja, misalnya budidaya tanaman hias, tanaman obat, sayur, pembibitan ikan hias dan konsumsi, pengolahan/pembuatan abon, kerupuk, ikan asin, bakso dll. Setelah mengikuti muatan lokal, peserta didik tidak mendapatkan sertifikat sebagai pengakuan terhadap hasil belajarnya.

Pembelajaran muatan lokal akan lebih berarti bila dibuktikan dengan adanya sertifikat sehingga bisa dijadikan bekal dalam mencari pekerjaan. Sertifikat yang diperoleh akan memotivasi peserta didik untuk hadir mengikuti pembelajaran karena sangat dibutuhkan dalam mencari pekerjaan. Motivasi belajar merupakan kebutuhan untuk mengembangkan kemampuan diri secara optimal, sehingga mampu berbuat yang lebih baik, berprestasi, dan kreatif (Abraham Maslow dalam Nashar, 2004). Motivasi belajar yang dimiliki peserta didik dalam setiap kegiatan pembelajaran sangat berperan untuk meningkatkan hasil belajarnya (Nashar, 2004). Dengan adanya motivasi belajar, peserta didik akan mampu mengelola sumber-sumber kognitif untuk menciptakan pengetahuan baru dengan mengekstrak informasi dari lingkungannya dan mengintegrasikannya dengan pengetahuan yang tersimpan di benaknya.

Dalam rangka menyiapkan sumber daya manusia (SDM) bangsa Indonesia untuk memasuki tatanan masyarakat informasi dunia, 
diperlukan pengembangan yang diharapkan dapat mendayagunakan infrastruktur teknologi informasi dan komunikasi (TIK). Tuntutan dunia industri untuk selalu menggunakan TIK dengan standar Computer Literate Certification (CLC) sangat tinggi, baik secara kualitas maupun kuantitas. Komputer telah digunakan untuk aplikasi bisnis selama lebih dari lima puluh tahun. Selama itulah terjadi peningkatan secara dramatis pada perangkat keras (hardware) dan perangkat lunak (software) sehingga keuntungan-keuntungan dari penggunaan komputer dapat dinikmati oleh berbagai institusi maupun pribadi. Untuk itu perlu disiapkan SDM yang berkompeten sesuai kebutuhan dunia usaha dan dunia industri (DUDI) melalui proses pembelajaran yang berkelanjutan dan sistematis, terstruktur, terprogram dan terukur.

Gagne dan Briggs sebagaimana dipaparkan oleh Gredler (1991) mendefinisikan belajar sebagai seperangkat proses kognitif yang mengubah sifat stimulasi dari lingkungan menjadi beberapa tahapan pengolahan informasi yang diperlukan untuk memeroleh kapabilitas yang baru. Sedangkan Rusyan (1989) mengungkapkan bahwa belajar adalah suatu proses perubahan tingkah laku individu melalui interaksi dengan lingkungan. Senada dengan ungkapan tersebut, Imron (1996) mengatakan bahwa belajar adalah suatu aktivitas yang dirancang atau sebagai akibat interaksi antara individu dengan lingkungannya. Roestiyah (1995) menyatakan bahwa belajar adalah suatu proses aktivitas yang dapat membawa perubahan bagi individu. Hasil penelitian Rahmayanti (2016) salah satunya menyatakan tingkat minat belajar siswa dan persepsi atas upaya guru dalam memotivasi belajar siswa terhadap prestasi belajar bahasa Indonesia siswa signifikan. Sama halnya penelitian Putra dkk (2017) yang melakukan intervensi melalui pembelajaran mandiri pada PKBM Paket $\mathrm{C}$ dimana ada peningkatan dari aspek kognitif, afektif dan psikomotor meski tidak terlalu signifikan. Menurut Surjadi (1989) perubahan yang terjadi pada belajar antara lain: (1) penambahan informasi, (2) pengembangan atau peningkatan pengertian, (3) penerimaan sikap-sikap baru, (4) perolehan penghargaan baru, dan (5) pengerjaan sesuatu dengan menggunakan yang telah dipelajari. Berdasarkan kajian teori di atas maka pembelajaran komputer program Microsoft Word dalam penelitian ini merupakan interaksi antara instruktur komputer dan peserta didik Paket $C$ dalam memenuhi mata pelajaran Muatan Lokal yang dilaksanakan di lembaga kursus dan pelatihan (LKP).

Sebagai rujukan nasional bagi upaya-upaya meningkatkan mutu dan daya saing bangsa Indonesia di sektor sumber daya manusia maka pemerintah telah mengembangkan Kerangka Kualifikasi Nasional Indonesia (KKNI) untuk menjadi suatu pencapaian setiap tingkat kualifikasi sumber daya manusia Indonesia berhubungan langsung dengan tingkat capaian pembelajaran baik yang dihasilkan melalui sistem pendidikan maupun sistem pelatihan kerja yang dikembangkan dan diberlakukan secara nasional. Oleh karena itu upaya peningkatan mutu dan daya saing bangsa akan sekaligus pula memperkuat jati diri bangsa Indonesia. KKNI merupakan salah satu langkah untuk mewujudkan mutu dan jati diri bangsa Indonesia dalam sektor SDM yang dikaitkan dengan program pengembangan sistem pendidikan dan pelatihan secara nasional. Setiap tingkat kualifikasi yang dicakup dalam KKNI memiliki makna dan kesetaraan dengan capaian pembelajaran yang dimiliki setiap insan pekerja Indonesia dalam menciptakan hasil karya dan kontribusi yang bermutu di bidang pekerjaannya masing-masing.

Untuk memfasilitasi pembelajaran komputer maka penyelenggara Paket $C$ dapat bermitra dengan Lembaga Kursus dan Pelatihan (LKP) dengan jenis kompetensi komputer. Setelah peserta didik berhasil mencapai kompetensinya maka LKP akan mengeluarkan sertifikat komputer sebagai bekal peserta didik dalam bekerja. Pembelajaran komputer dalam penelitian ini adalah proses interaksi antara peserta didik dengan instruktur kursus komputer pada suatu lingkungan belajar tertentu untuk menjadikan peserta didik menguasai keterampilan komputer yang dibuktikan dengan sertifikat dari LKP sebagai suplemen untuk memasuki dunia kerja.

Pendidikan Kesetaraan Paket $C$ dalam penelitian ini difokuskan pada penyelenggaraan pembelajaran komputer program mocrosoft word bagi peserta didik Paket C Tingkatan VI Derajat Kompetensi Mahir 2 (Setara kelas XI SMA-IPS). Berdasarkan latar belakang maka artikel ini merupakan hasil dari penelitian yang bertujuan untuk: (1) Menemukan hasil pembelajaran komputer pada mata pelajaran Muatan Lokal Paket C, dan (2) Mengetahui efektivitas pembelajaran komputer pada mata pelajaran Muatan Lokal Paket C.

Di dalam Peraturan Pemerintah (PP) No. 13 Tahun 2015 Tentang Perubahan Kedua dari PP No. 19 Tahun 2005 Tentang Standar Nasional Pendidikan dinyatakan bahwa Standar Kompetensi Lulusan adalah kriteria mengenai kualifikasi kemampuan lulusan yang mencakup sikap, pengetahuan, dan keterampilan. Kompetensi lulusan pada pembelajaran komputer program microsoft word pada penelitian 
ini merujuk pada standar kompetensi lulusan (SKL) Komputer Direktorat Pembinaan Kursus dan Pelatihan Tahun 2011. Kompetensi lulusan bertujuan menumbuhkembangkan kemampuan (kompetensi) pada program microsoft word yang dirinci dalam cakupan berikut:

Tabel 1.

SKL Komputer Program Microsoft Word

\begin{tabular}{|c|c|}
\hline Sikap & $\begin{array}{l}\text { Penerapan nilai-nilai, sikap, dan etika kerja serta kemampuan berkomunikasi guna menjadi operator } \\
\text { komputer yang profesional. }\end{array}$ \\
\hline Pengetahuan & $\begin{array}{l}\text { 1.Pemahaman tentang pengetahuan mengenai hal-hal yang berkaitan dengan prinsip-prinsip dan ele- } \\
\text { men-elemen kompetensi yang dibutuhkan untuk mengoperasikan komputer program microsoft word, } \\
\text { meliputi: } \\
\text { a. Menerapkan prosedur keselamatan kerja. } \\
\text { b. Mengidentifikasi aspek kode etik dan HAKI di bidang TIK } \\
\text { c. Sistem Operasi (Operating System) } \\
\text { d. Instalasi Piranti lunak (Software) } \\
\text { e. Pengolah Kata (Word Processing) } \\
\text { f. Pengoperasian Browser dan e-mail } \\
\text { g. Pengoperasian piranti lunak khusus/Pengenalan PDF } \\
\text { 2. Pengetahuan IImu dan perkembangan komputer kekinian. }\end{array}$ \\
\hline Keterampilan & $\begin{array}{l}\text { Kemampuan-kemampuan dalam lingkup pekerjaan yang berkaitan dengan pemanfaatan Komputer (ICT) } \\
\text { dalam berbagai cabang kegiatan yang dibutuhkan dunia kerja }\end{array}$ \\
\hline
\end{tabular}

Menurut Darsono (2001) proses pembelajaran secara umum merupakan suatu kegiatan yang mengakibatkan terjadinya perubahan tingkah laku. Oleh karena itu perlu disusun struktur kurikulum yang akan mewujudkan standar kompetensi yang akan diraih oleh peserta didik. Struktur kurikulum pada pembelajaran komputer dalam penelitian ini merujuk pada Kurikulum Berbasis Kompetensi (KBK) Komputer Aplikasi Perkantoran Direktorat Pembinaan Kursus dan Pelatihan Tahun 2009 dan disesuaikan dengan sistem kredit kompetensi (SKK) mata pelajaran Muatan Lokal. Adapun struktur kurikulum tersebut adalah sebagai berikut.

Tabel 2.

Struktur Kurikulum Komputer Program Pengolah Kata/Microsoft Word

\begin{tabular}{clr}
\hline No. & \multicolumn{1}{c}{ Standar Kompetensi } & Waktu \\
\hline 1 & $\begin{array}{l}\text { Menerapkan prosedur keselamatan } \\
\text { kerja }\end{array}$ & 4 JP \\
2 & $\begin{array}{l}\text { Mengidentifikasi aspek kode etik dan } \\
\text { HAKI di bidang TIK }\end{array}$ & 2 JP \\
3 & $\begin{array}{l}\text { Mengoperasikan sistem operasi } \\
4\end{array}$ & $\begin{array}{l}\text { Mengoperasikan piranti lunak pengolah } \\
\text { kata (wordprocesing) }\end{array}$ \\
5 & $\begin{array}{l}\text { Mengoperasikan piranti lunak browser } \\
\text { dan email }\end{array}$ & 12 JP \\
6 & $\begin{array}{l}\text { Mengoperasikan piranti lunak khusus/ } \\
\text { Pengenalan PDF }\end{array}$ & 4 JP \\
\hline & \multicolumn{2}{c}{ Jumlah } \\
\hline
\end{tabular}

Pembelajaran komputer dilaksanakan di LKP terdekat, sehingga mudah dijangkau oleh peserta didik. Untuk kemitraan ini diperlukan adanya kesepakatan kerja sama dalam memfasilitasi pembelajaran bagi peserta didik Paket $C$, sehingga hasil pembelajaran di
LKP dapat dimasukkan ke dalam nilai rapor peserta didik Paket $\mathrm{C}$ untuk mata pelajaran muatan lokal. Kegiatan pembelajaran dilaksanakan dua hari dalam seminggu selama 3 jam pelajaran setiap pertemuan, sehingga seluruhnya berjumlah 20 pertemuan. Struktur kurikulum tersebut dijabarkan ke dalam standar isi yang memuat Standar Kompetensi (SK) dan Kompetensi Dasar (KD) berikut.

Tabel 3.

Standar Isi Program Pengolah Kata/Microsoft Word

\begin{tabular}{|c|c|c|}
\hline $\mathrm{NO}$ & $\begin{array}{l}\text { STANDAR KOM- } \\
\text { PETENSI }\end{array}$ & KOMPETENSI DASAR \\
\hline 1 & $\begin{array}{l}\text { Menerapkan } \\
\text { prosedur kesela- } \\
\text { matan kerja }\end{array}$ & $\begin{array}{l}\text { 1.1.Menerapkan hal-hal yang ber- } \\
\text { hubungan dengan kesehatan dan } \\
\text { keselamatan kerja di lingkungan } \\
\text { kerja } \\
\text { 1.2. Mendokumentasikan dan } \\
\text { menyebarkan syarat-syarat keseha- } \\
\text { tan dan keselamatan kerja }\end{array}$ \\
\hline 2 & $\begin{array}{l}\text { Mengidentifikasi } \\
\text { aspek kode etik } \\
\text { dan HAKI dibidang } \\
\text { TIK }\end{array}$ & $\begin{array}{l}\text { 2.1. Mengidentifikasi kode etik yang } \\
\text { berlaku di dunia TIK } \\
\text { 2.2.Mengidentifikasi hal-hal yang } \\
\text { berkaitan dengan HAKI TIK }\end{array}$ \\
\hline 3 & $\begin{array}{l}\text { Mengoperasikan } \\
\text { Sistem operasi }\end{array}$ & $\begin{array}{l}\text { 3.1.Memahami konsep dasar } \\
\text { komputer } \\
\text { 3.2.Mengoperasikan komputer } \\
\text { 3.3.Menjaga keamanan file/folder } \\
\text { serta kinerja sistem computer }\end{array}$ \\
\hline 4 & $\begin{array}{l}\text { Mengoperasikan } \\
\text { piranti lunak } \\
\text { Pengolah kata } \\
\text { (wordprocessing) }\end{array}$ & $\begin{array}{l}\text { 4.1.Mengenali dan mengetahui } \\
\text { berbagai piranti lunak yang terma- } \\
\text { suk dalam pengolah kata } \\
\text { 4.2.Membuat dokumen } \\
\text { 4.3.Menggunakan fungsi menu bar } \\
\text { dan menu toolbar } \\
\text { 4.4.Membuat naskah dengan } \\
\text { format Indentasi (Format paragraf, } \\
\text { bullets,numbering, tabulasi) } \\
\text { 4.5.Membuat naskah dengan } \\
\text { format kolom } \\
\text { 4.6.Membuat naskah dengan } \\
\text { format table } \\
\text { 4.7.Membuat naskah surat missal } \\
\text { 4.8.Menggunakan fitur } \\
\text { 4.9.Mencetak dokumen }\end{array}$ \\
\hline
\end{tabular}




\begin{tabular}{lll}
\hline 5 & Mengoperasikan & 5.1.Mengetahui berbagai piranti \\
piranti lunak brows- & lunak browser dan email client \\
er dan Email & 5.2.Mengoperasikan web browser \\
& dan email client \\
& 5.3.Menerapkan fungsi menu dan \\
& toolbar \\
& 5.4.Mengoperasikan email \\
& 5.5.Mencetak dan menyimpan infor- \\
& masi dari web dan email \\
\hline
\end{tabular}

\begin{tabular}{lll}
\hline 6 & Mengoperasikan & 6.1. Mempersiapkan piranti lunak \\
piranti lunak khu- & aplikasi PDF \\
sus PDF & $\begin{array}{l}\text { 6.2.Menjalankan piranti lunak } \\
\text { aplikasi PDF }\end{array}$ \\
&
\end{tabular}

Proses penyelenggaraan peminatan vokasi dapat divisualisasikan dalam bentuk gambar berikut:

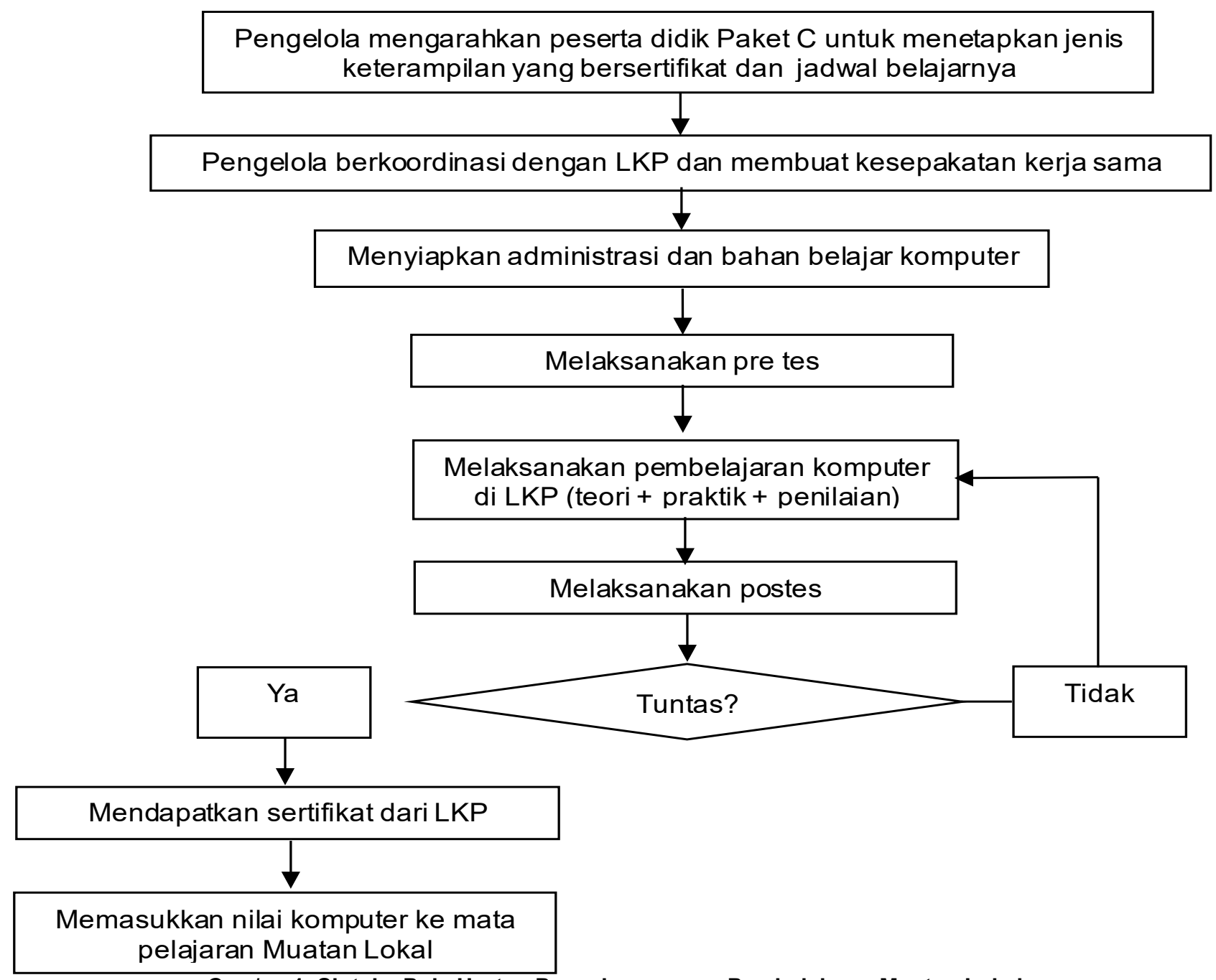

Gambar 1. Sintaks Pola Urutan Penyelenggaraan Pembelajaran Muatan Lokal

Sebagaimana tertera di dalam PP No. 13 Tahun 2015, bahwa kompetensi adalah seperangkat sikap, pengetahuan, dan keterampilan, yang harus dimiliki, dihayati, dan dikuasai oleh Peserta Didik setelah mempelajari suatu muatan pembelajaran, menamatkan suatu program, atau menyelesaikan satuan pendidikan tertentu. Sebagai bentuk pengakuan akan kompetensi yang dimiliki setiap peserta didik yang telah mengikuti pembelajaran komputer maka bagi yang lulus akan diberikan sertifikat dari LKP.

\section{METODE PENELITIAN}

Penelitian ini adalah penelitian eksperimen yang dilakukan di empat Satuan Pendidikan Nonformal (SPNF) yaitu Pusat Kegiatan Belajar Masyarakat (PKBM) Cendana Deli Serdang, PKBM Prestasi Gemilang Deli Serdang, PKBM Al Habib Serdang Bedagai, dan PKBM Nur Habibi Serdang Bedagai. Waktu penelitian pada bulan Agustus s.d Oktober 2017. Intervensi yang dilakukan sebanyak 20 kali pertemuan atau 60 jam pelajaran, dengan rincian 3 hari per minggu. Setiap pertemuan masing-masing 3 jam, dimana 1 jam pelajaran dilaksanakan selama 60 menit.

Populasi dalam penelitian ini adalah peserta didik paket C Tingkatan VI Derajat Kompetensi Mahir 2 berjumlah 60 orang sedangkan sampelnya adalah peserta komputer berjumlah 33 orang. Pemilihan satuan pendidikan sebagai sampel penelitian 
ditetapkan berdasarkan teknik sampling bertujuan (purpossive sampling), dengan kriteria: (1) Memiliki akte notaris, (2) memiliki ijin operasional, (3) memiliki Nomor Pokok Sekolah Nasional (NPSN), (4) bersedia menjalin kerja sama dengan LKP, (5) tersedia kursus komputer yang mudah dijangkau peserta didik. Penelitian ini menggunakan desain eksperimen semu (quasi experiment design) dengan pretest dan posttest. $\mathrm{O}_{1} \times \mathrm{O}_{2}$

Keterangan : $\mathrm{O}_{1}$

: Tes awal

$X$

: Perlakuan

$\mathrm{O}_{2} \quad:$ Tes akhir

Dalam penelitian ini digunakan instrumen untuk mengukur hasil belajar dalam bentuk tes berjumlah 20 soal pilihan ganda dengan 4 pilihan jawaban. Berbagai data/informasi yang ditemukan dianalisis dengan metode induktif, artinya berbagai data/informasi mula-mula dianalis dari yang khusus menuju ke yang umum. Analisis ini dapat diartikan pula menganalisis data/informasi dari yang kecil menuju ke yang besar. Setiap temuan akan dimaknai sehingga benar-benar berarti. Untuk mengetahui tingkat efektivitas program dilakukan dengan analisa kuantitatif. Data yang dikumpul dianalisis dengan menggunakan statistik sederhana dengan menentukan rata-rata kelas sebagai daya serap klasikal. Hasil penghitungan tersebut diinterpretasikan berdasarkan kategori berikut:

$$
\begin{array}{ll}
85<\text { nilai } \leq 100 & : \text { Sangat Baik } \\
70<\text { nilai } \leq 85 & : \text { Baik } \\
55<\text { nilai } \leq 70 & : \text { Cukup Baik } \\
40<\text { nilai } \leq 55 & : \text { Kurang Baik } \\
\leq 40 & : \text { Tidak Baik }
\end{array}
$$

Untuk mengetahui signifikansi program diuji dengan t-test berkorelasi dengan rumus:

$$
\begin{aligned}
& \mathrm{t}= \\
& \mathrm{D}=\mathrm{X}_{2}-X_{1} \\
& \frac{\bar{D}}{\sqrt{\frac{\sum d^{2}}{n(n-1)}}} \\
& \bar{D}=\sum D \\
& \mathrm{~d}=\mathrm{D}^{n}-\bar{D} \\
& \text { derajat kebebasan }(\mathrm{dk})=\mathrm{n}-1
\end{aligned}
$$

\section{HASIL DAN PEMBAHASAN}

\section{Hasil Belajar Komputer Paket C}

Hasil belajar adalah tingkat penguasaan suatu pengetahuan yang dicapai oleh peserta didik dalam mengikuti pembelajaran sesuai dengan tujuan yang ditetapkan (Gagne dalam Reiser dan Dempsey, 2007). Reigeluth (1983) berpendapat bahwa hasil belajar dirumuskan sebagai perilaku yang dapat diamati dan dapat menunjukkan kemampuan seseorang. Meril, sebagaimana dinyatakan Reigeluth (1983) merinci hasil belajar, yaitu: mengingat, mengaplikasikan, dan menemukan segi isi pelajaran meliputi: fakta, konsep, prosedur, dan prinsip Dengan demikian dapat dikatakan bahwa hasil belajar adalah kemampuankemampuan yang diperoleh peserta didik setelah menerima pengalaman belajarnya.

Berdasarkan deskripsi teoretis hasil belajar di atas maka yang dimaksud hasil belajar komputer dalam penelitian ini adalah data taraf keberhasilan pembelajaran peserta didik sebagai gambaran kemampuan mutu yang dimilikinya dan ditunjukkan melalui proses pengujian yang sistematis. Pengukuran hasil belajar tersebut dilakukan setelah peserta didik menerima pengalaman belajar yang dinyatakan dalam standar kompetensi dan kompetensi dasar komputer program Microsoft Word. Pengukuran hasil belajar dilakukan dengan menggunakan instrumen tes hasil belajar secara tertulis dalam bentuk pilihan ganda yang terbatas pada ranah kognitif menurut Bloom, meliputi pengetahuan, pemahaman, penerapan, dan analisis. Hasil belajar tersebut dinyatakan dengan skor.

Hasil belajar yang menjadi fokus dalam penelitian ini adalah hasil belajar Komputer program Microsoft Word. Hasil tes awal dan tes akhir dapat dideskripsikan pada Tabel 4 berikut ini: 
Tabel 4.

Hasil Tes Awal dan Tes Akhir

\begin{tabular}{|c|c|c|c|c|}
\hline \multirow{2}{*}{ No. } & \multirow{2}{*}{ Nama } & \multicolumn{2}{|c|}{ Nilai } & \multirow{2}{*}{$\begin{array}{l}\text { Satuan Pendi- } \\
\text { dikan }\end{array}$} \\
\hline & & Pretes & Postes & \\
\hline 1. & DA & 40 & 60 & \multirow[t]{8}{*}{ PKBM Cendana } \\
\hline 2. & C & 70 & 80 & \\
\hline 3. & $F$ & 40 & 60 & \\
\hline 4. & $\mathrm{H}$ & 70 & 80 & \\
\hline 5. & MA & 70 & 80 & \\
\hline 6. & $S$ & 70 & 80 & \\
\hline 7. & SA & 70 & 80 & \\
\hline 8. & YK & 10 & 60 & \\
\hline 9. & DBA & 70 & 80 & \multirow{9}{*}{$\begin{array}{l}\text { PKBM Prestasi } \\
\text { Gemilang }\end{array}$} \\
\hline 10. & DS & 70 & 70 & \\
\hline 11. & $\mathrm{Ka}$ & 50 & 70 & \\
\hline 12. & $\mathrm{Ki}$ & 60 & 70 & \\
\hline 13. & MEF & 60 & 80 & \\
\hline 14. & MB & 50 & 60 & \\
\hline 15. & Su & 40 & 60 & \\
\hline 16. & Sy & 40 & 60 & \\
\hline 17. & WP & 60 & 80 & \\
\hline 18. & ASNM & 40 & 70 & \multirow[t]{9}{*}{ PKBM Al Habib } \\
\hline 19. & $A D$ & 90 & 90 & \\
\hline 20. & DR & 50 & 80 & \\
\hline 21. & ENA & 50 & 100 & \\
\hline 22. & MI & 60 & 90 & \\
\hline 23. & MD & 40 & 80 & \\
\hline 24. & RS & 40 & 100 & \\
\hline 25. & VAi & 30 & 100 & \\
\hline 26. & VAa & 90 & 70 & \\
\hline 27. & BS & 40 & 60 & \multirow[t]{7}{*}{ PKBM Nur Habibi } \\
\hline 28. & FR & 30 & 60 & \\
\hline 29. & MR & 40 & 70 & \\
\hline 30. & MI & 70 & 80 & \\
\hline 31. & RW & 30 & 60 & \\
\hline 32. & W & 50 & 70 & \\
\hline 33. & $\mathrm{Y}$ & 40 & 70 & \\
\hline \multicolumn{2}{|c|}{ Jumlah Nilai } & 1730 & 2460 & \\
\hline \multicolumn{2}{|c|}{ Nilai rata-rata } & 52,4 & 74,5 & \\
\hline
\end{tabular}

Berdasarkan Tabel 4, dapat dilihat bahwa hasil tes awal berada pada rentang nilai 10 hingga 90 dengan nilai rata-rata 52,4 (termasuk dalam kategori kurang baik). Sedangkan hasil tes akhir berada pada rentang nilai 60 hingga 100 dengan nilai ratarata 74,5 (termasuk dalam kategori baik). Terdapat kenaikan nilai rata-rata tes awal dan tes akhir, yaitu $\frac{74,5-52,4}{52,4} \times 100 \%=42,2 \%$ dengan daya serap klasikal $74,5 \%$. Untuk mengetahui signifikansi program dilakukan uji t-test berkorelasi (dependent sample) dengan rumus:

$$
\mathrm{t}=\frac{\bar{D}}{\sqrt{\frac{\sum d^{2}}{n(n-1)}}} \quad \begin{aligned}
& \bar{D}=\frac{\sum D}{2}-X_{1} \\
& \mathrm{~d}=\mathrm{D}-\frac{n}{D} \\
& \text { derajat kebebasan }(\mathrm{dk})=\mathrm{n}-1
\end{aligned}
$$

Keterangan:

$\mathrm{t}=$ perbedaan dua rata-rata

$\mathrm{X}_{1}=$ nilai pretest

$\mathrm{X}_{2}=$ nilai posttest

$\mathrm{n}=$ jumlah subjek (peserta didik)

Tabel 5.

Rincian Uji t

\begin{tabular}{lllllll}
\hline No. & NAMA & $\mathbf{X}_{1}$ & $\mathbf{X}_{2}$ & \multicolumn{1}{c}{$\mathbf{D}$} & \multicolumn{1}{c}{$\mathbf{d}$} & \multicolumn{1}{c}{$\mathbf{d}^{2}$} \\
\hline 1. & DA & 40 & 60 & 20 & -2.12 & 4.5 \\
2. & $\mathrm{C}$ & 70 & 80 & 10 & -12.12 & 146.9 \\
3. & $\mathrm{F}$ & 40 & 60 & 20 & -2.12 & 4.5 \\
4. & $\mathrm{H}$ & 70 & 80 & 10 & -12.12 & 146.9 \\
5. & MA & 70 & 80 & 10 & -12.12 & 146.9 \\
6. & $\mathrm{S}$ & 70 & 80 & 10 & -12.12 & 146.9 \\
7. & SA & 70 & 80 & 10 & -12.12 & 146.9 \\
8. & YK & 10 & 60 & 50 & 27.88 & 777.3 \\
9. & DBA & 70 & 80 & 10 & -12.12 & 146.9 \\
10. & DS & 70 & 70 & 0 & -22.12 & 489.3 \\
11. & Ka & 50 & 70 & 20 & -2.12 & 4.5 \\
12. & Ki & 60 & 70 & 10 & -12.12 & 146.9 \\
13. & MEF & 60 & 80 & 20 & -2.12 & 4.5 \\
14. & MB & 50 & 60 & 10 & -12.12 & 146.9 \\
15. & Su & 40 & 60 & 20 & -2.12 & 4.5 \\
16. & Sy & 40 & 60 & 20 & -2.12 & 4.5 \\
17. & WP & 60 & 80 & 20 & -2.12 & 4.5 \\
18. & ASNM & 40 & 70 & 30 & 7.88 & 62.1 \\
19. & AD & 90 & 90 & 0 & -22.12 & 489.3 \\
20. & DR & 50 & 80 & 30 & 7.88 & 62.1 \\
21. & ENA & 50 & 100 & 50 & 27.88 & 777.3 \\
22. & MI & 60 & 90 & 30 & 7.88 & 62.1 \\
23. & MD & 40 & 80 & 40 & 17.88 & 319.7 \\
24. & RS & 40 & 100 & 60 & 37.88 & 1434.9 \\
25. & VAi & 30 & 100 & 70 & 47.88 & 2292.5 \\
26. & VAa & 90 & 70 & -20 & -42.12 & 1774.1 \\
27. & BS & 40 & 60 & 20 & -2.12 & 4.5 \\
28. & FR & 30 & 60 & 30 & 7.88 & 62.1 \\
29. & MR & 40 & 70 & 30 & 7.88 & 62.1 \\
30. & MI & 70 & 80 & 10 & -12.12 & 146.9 \\
31. & RW & 30 & 60 & 30 & 7.88 & 62.1 \\
32. & W & 50 & 70 & 20 & -2.12 & 4.5 \\
33. & $\mathrm{Y}$ & 40 & 70 & 30 & 7.88 & 62.1 \\
\hline Jumlah & & & 730 & & 10151,5 \\
\hline & & & & & & \\
\hline
\end{tabular}




$$
\begin{aligned}
\bar{D} & =\frac{\sum D=\frac{730}{3}}{n}=22,12 \text { dan } \mathrm{d}=\mathrm{D}-\bar{D} \\
\mathrm{t} & =\frac{\sqrt{\frac{\sum d^{2}}{n(n-1)}}}{\sqrt{\frac{10151,5}{3(3-1)}}}=\frac{2, \mathbb{L}}{\sqrt{\frac{10151,5}{1056}}}=\frac{2, \mathbb{L}}{\sqrt{9,6}}=\frac{2, \mathbb{L}}{3,1}=7,14 \\
& =\frac{2, \mathbb{L}}{\sqrt{3,1}}
\end{aligned}
$$

$$
\text { Dengan demikian } \mathrm{t}_{\text {hitung }}=7,14
$$

Derajat kebebasan ( $\mathrm{dk}$ ) adalah $=\mathrm{n}-1=33-1$ $=32$. Nilai ini dikonfirmasi ke dalam daftar Distribusi $\mathrm{t}$ dengan taraf signifikansi $5 \%$ dan terlihat $\mathrm{t}_{\text {tabel }}=2,04$. Pada taraf signifikansi 0,05 terlihat nilai $\mathbf{t}_{\text {hitung }}>\mathbf{t}_{\text {tabel }}$ $(7,14>2,04)$ sehingga dapat disimpulkan bahwa terdapat perbedaan yang signifikan nilai yang diperoleh peserta didik sebelum dengan sesudah melaksanakan pembelajaran komputer pada taraf signifikansi $5 \%$. Sebagai tindak lanjut pembelajaran komputer pada mata pelajaran muatan lokal Paket $\mathrm{C}$ maka peserta didik diberikan sertifikat komputer program Microsoft Word dari LKP. Kemudian nilai yang diperoleh dari LKP akan menjadi nilai raport peserta didik untuk mata pelajaran muatan lokal.

\section{Pembahasan}

Hasil penelitian ini telah membuktikan secara signifikan bahwa terdapat perbedaan nilai yang diperoleh peserta didik Paket $\mathrm{C}$ sebelum dengan sesudah mengikuti pembelajaran komputer pada taraf signifikansi $5 \%$ yang terlihat dari nilai $\mathrm{t}_{\text {hitung }}>\mathrm{t}$ tabel $(7,14>2,04)$. Nilai peserta didik Paket $C$ setelah belajar komputer lebih tinggi dari sebelum belajar komputer dengan kenaikan nilai rata-rata sebesar $42,2 \%$ dan daya serap klasikal sebesar $74,5 \%$ (termasuk dalam kategori baik). Hal ini menunjukkan indikasi bahwa pembelajaran komputer sangat tepat diberikan kepada peserta didik Paket $\mathrm{C}$.

Dalam pembelajaran muatan lokal, satuan pendidikan harus menyusun SK, KD dan silabus untuk mata pelajaran Muatan lokal yang diselenggarakan. Pembelajarannya dapat dilakukan oleh tutor mata pelajaran atau tenaga ahli dari luar satuan pendidikan yang relevan dengan substansi Muatan lokal. Standar kompetensi lulusan pada pembelajaran komputer yang diberikan kepada peserta didik Paket $\mathrm{C}$ mengacu pada Kerangka Kualifikasi Nasional Indonesia (Indonesia Qualification Framework) Kursus dan Pelatihan Komputer dari Direktorat Pembinaan Kursus dan
Pelatihan Tahun 2011, sedangkan kurikulumnya mengacu pada KBK Komputer Aplikasi Perkantoran dari Direktorat Pembinaan Kursus dan Pelatihan Tahun 2009 yang disesuaikan dengan ketersediaan waktu belajar peserta didik Paket $\mathrm{C}$ karena selain belajar komputer, peserta didik juga belajar akademik sesuai mata pelajaran akademik di Paket C. Oleh karena itu maka strategi pembelajaran dilakukan dengan tatap muka dan mandiri sebagaimana dapat dilihat pada tabel berikut:

Tabel 6.

Analisis Struktur Materi Komputer Program Microsoft Word Pada Mata Pelajaran Muatan Lokal Paket C

\begin{tabular}{cllcl}
\hline No. & Standar Kompetensi & $\begin{array}{c}\text { Alokasi } \\
\text { Waktu }\end{array}$ & $\begin{array}{c}\text { Tatap } \\
\text { Muka }\end{array}$ & Mandiri \\
\hline 1 & $\begin{array}{l}\text { Melaksanakan } \\
\text { prosedur kesehatan } \\
\text { dan keselamatan kerja } \\
\text { (K3) }\end{array}$ & 6 jam & 4 jam & 6 jam \\
2 & $\begin{array}{l}\text { Menyiapkan tempat } \\
\text { kerja }\end{array}$ & 4 jam & & \\
3 & $\begin{array}{l}\text { Mengidentifikasi aspek } \\
\text { kode etik dan HAKI di } \\
\text { bidang TIK }\end{array}$ & 4 jam & 2 jam & \\
4 & $\begin{array}{l}\text { Mengoperasikan } \\
\text { Sistem operasi }\end{array}$ & 6 jam & 12 jam & \\
5 & $\begin{array}{l}\text { Menginstalasi piranti } \\
\text { lunak }\end{array}$ & 2 jam & 26 jam & \\
6 & $\begin{array}{l}\text { Mengoperasikan piran- } \\
\text { ti lunak Pengolah kata } \\
\text { (wordprocessing) }\end{array}$ & 20 jam & & \\
7 & $\begin{array}{l}\text { Mengoperasikan piran- } \\
\text { ti lunak browser dan }\end{array}$ & 12 jam & 12 jam & \\
\hline 8 & $\begin{array}{l}\text { Email } \\
\text { Mengoperasikan } \\
\text { piranti lunak khusus/ } \\
\text { Pengenalan PDF }\end{array}$ & 6 jam & 4 jam & 2 jam \\
\hline Jumlah & $\mathbf{6 0 ~ j a m ~}$ & $\mathbf{6 0}$ jam & $\mathbf{8}$ jam \\
\hline
\end{tabular}

Kegiatan pembelajaran komputer untuk materi yang sifatnya teori dilaksanakan secara tatap muka dan mandiri. Contohnya untuk materi Prosedur K3 dan Menyiapkan Tempat Kerja berjumlah 10 jam, namun kedua materi ini digabung dan tatap muka hanya dilaksanakan 4 jam, sedangkan 6 jam lagi dipenuhi secara mandiri dengan membaca diktat. Demikian juga untuk materi Aspek Kode Etik dan HAKI di Bidang TIK berjumlah 4 jam namun pembelajaran tatap muka hanya 2 jam selebihnya mandiri. Demikian halnya dengan materi Piranti Lunak Khusus/Pengenalan PDF dengan alokasi waktu 6 jam, dilaksanakan secara tatap muka 4 jam dan mandiri 2 jam. Materi Menginstalasi Piranti Lunak dan Wordprocessing digabung karena banyak kesamaan dan waktunya ditambah dari 22 jam menjadi 26 jam karena sifatnya praktik sehingga membutuhkan banyak waktu berlatih di LKP, mengingat peserta didik Paket $C$ tidak memiliki komputer. 
Pembelajaran tatap muka merupakan interaksi antara instruktur komputer dan peserta didik dalam bentuk teori dan praktik dengan perbandingan 30\% teori dan $70 \%$ praktik. Kegiatan mandiri adalah kegiatan peserta didik belajar secara individu yang dibekali diktat atau bahan ajar sesuai materi yang dipelajari.
Pembelajaran tatap muka dilaksanakan sebanyak 20 pertemuan atau 3 jam setiap pertemuan. Sesuai standar kursus maka 1 jam pelajaran dilaksanakan selama 60 menit, sedangkan pembelajaran mandiri disesuaikan dengan ketersediaan waktu masingmasing peserta didik.

\section{PENUTUP}

\section{Kesimpulan}

Pembelajaran komputer program Microsoft Word dalam penelitian ini merupakan interaksi antara instruktur komputer dan peserta didik Paket C dalam memenuhi mata pelajaran muatan lokal yang dilaksanakan di lembaga kursus dan pelatihan (LKP). Kompetensi lulusan pada pembelajaran komputer program microsoft word pada penelitian ini merujuk pada standar kompetensi lulusan (SKL) Komputer Direktorat Pembinaan Kursus dan Pelatihan Tahun 2011. Sedangkan struktur kurikulum pada pembelajaran komputer ini merujuk pada KBK Komputer Aplikasi Perkantoran Direktorat Pembinaan Kursus dan Pelatihan Tahun 2009 dan disesuaikan dengan Satuan Kredit Kompetensi (SKK) mata pelajaran muatan lokal Paket C. Setelah mengikuti pembelajaran di LKP dan dinyatakan tuntas, peserta didik menerima sertifikat dari LKP dan nilai yang diperoleh dari LKP menjadi nilai rapor peserta didik Paket $\mathrm{C}$ untuk mata pelajaran muatan lokal.

Dari hasil postest, diketahui nilai peserta didik Paket $C$ setelah belajar komputer lebih tinggi dari sebelum belajar komputer dengan kenaikan nilai ratarata sebesar $42,2 \%$ dan daya serap klasikal sebesar $74,5 \%$ (termasuk dalam kategori baik). Sedangkan penghitungan uji $t$ diketahui bahwa nilai $t_{\text {hitung }}>$ nilai $t_{\text {tabel }}(7,14>2,04)$, sehingga dapat disimpulkan bahwa pembelajaran komputer program Microsoft Word efektif dilaksanakan bagi peserta didik pendidikan kesetaraan Paket C.

Untuk lebih jauh intervensi pembelajaran computer ini dilaksanakan, maka saran yang dapat diberikan adalah :

1. Pembelajaran muatan lokal Paket $C$ sebaiknya bermitra dengan LKP agar peserta didik bisa memeroleh sertifikat sebagai suplemen dalam mencari pekerjaan.

2. Sebaiknya dalam memilih jenis muatan lokal, SPNF memerhatikan ketersediaan LKP terdekat sehingga mudah dijangkau peserta didik.

3. Sebelum melaksanakan pembelajaran muatan lokal di LKP, sebaiknya SPNF membuat perjanjian kerja sama sehingga masing-masing pihak memahami tugas dan tanggung jawab masing-masing.

Kepada satuan pendidikan, baik penyelenggara Paket C maupun LKP diharapkan dapat memfasilitasi peserta didik untuk uji kompetensi dengan cara mendaftarkan peserta didik ke tempat uji kompetensi terdekat sesuai jenis vokasi yang diikuti peserta didik Paket C.

\section{DAFTAR PUSTAKA}

Darsono, M. (2001). Belajar dan Pembelajaran. Semarang: Unnes Press.

Departemen Pendidikan Nasional. (2003). Undang-Undang Republik Indonesia No. 20 Tentang Sistem Pendidikan Nasional. Jakarta: Medya Duta

Depdiknas. (2007). Peraturan Menteri Pendidikan Nasional Nomor 14 Tahun 2007 tentang Standar Isi Untuk Program Paket A, Program Paket B, dan Program Paket C. Jakarta: 2007

Direktorat Pembinaan Kursus dan Kelembagaan. (2009). Kurikulum Berbasis Kompetensi Komputer Aplikasi Perkantoran. Jakarta: Ditjen PNFI.

Direktorat Pembinaan Kursus dan Pelatihan. (2011). Standar Kompetensi Lulusan Komputer. Jakar- ta: Ditjen PAUDNI.

Gredler, M. E. B. (1991). Belajar dan Membelajarkan (alih bahasa: Munandir). Jakarta: Rajawali Pers. Imron, A. (1996). Belajar dan Pembelajaran. Jakarta: PT. Dunia Pustaka Jaya

Kemdikbud. (2015). Peraturan Pemerintah (PP) No. 13 Tentang Perubahan Kedua Atas PP No. 19 Tentang Standar Nasional Pendidikan. Jakarta: Kemdikbu

Nashar. (2004). Peran Motivasi dan Kemampuan Awal Dalam Kegiatan Pembelajaran. Jakarta: Delia Press.

Pusat Data dan Statistik Pendidikan dan Kebudayaan. (2016). Statistik Pendidikan Non Formal 2015. 
Jakarta: Setjen, Kemendikbud.

Pusat Data dan Statistik Pendidikan dan Kebudayaan. (2017). Rangkuman Statistik Pendidikan Dasar dan Menengah 2017/2018. Jakarta: Setjen, Kemendikbud.

Putra, Riza Anugrah. (2017). Penerapan Metode Pembelajaran Mandiri dalam Meningkatkan Hasil Belajar Peserta Didik (Studi pada Program Pendidikan Kesetaraan Paket $C$ di PKBM Bina Mandiri Cipangeran). Jurnal Pendidikan Luar Sekolah, 1, (1), 23-36. Diakses melalui https://ejournal.upi.edu/index.php/pls/article/ view/8723/5413

Rahmayanti, Vina. (2016). Pengaruh Minat Belajar Siswa dan Persepsi atas Upaya Guru dalam Memotivasi Belajar Siswa terhadap Prestasi
Belajar Bahasa Indonesia Siswa SMP di Depok. Jurnal Susunan Artikel Pendidikan, 1 (2), 206-216, DOI: http://dx.doi.org/10.30998/sap. $\mathrm{v} 1 \mathrm{i} 2.1027$

Reigeluth, C.M. (1983). Introductional - Design Theoris and Models. London: Lawrence Erlbaum Assiciates, Publisher.

Reiser, R. A.,Dempsey, J. V. (2007). Trends and Issues in Instructional Design and Technology-2 ${ }^{\text {nd }}$ ed. Ohio: Person Merrill Prentice Hall.

Roestiyah (1995). Didaktik Metodik. Jakarta: Bumi Aksara.

Rusyan, A. T., dkk. (1989). Pendekatan Proses Belajar Mengajar. Bandung: CV. Remaja Rosdakarya.

Surjadi, A. (1989). Membuat Siswa Aktif Belajar. Bandung: Mandar Maju. 